\title{
An Understanding of the Students' Perception about COVID-19 Pandemic and its Impacts on Pakhtun Society
}

\author{
* Jan Alam, Lecturer (Corresponding Author) \\ ** Akhtar Munir, Assistant Profes sor \\ *** Nauman Tahir, MSc Sociology
}

\begin{abstract}
COVID-19 Pandemic has different effects on society. Its effects have been differently perceived by different classes; one such important class is the university students because they play an important role in the development of a society. To explore their perception, this article used an interpretive approach to understand its impacts on education, the economy, and socio-cultural practices. The researchers used in-depth open-ended interviews for data collection. The sample size of the study consisted of twenty-four students i.e. six each from FATA University, Kohat University of Science and Technology, Preston University, and University of Peshawar. The primary data were analyzed by using the thematic analysis technique. The results reveal that there are divergent beliefs and superstitions about the prevention and presence of coronavirus. These included conspiracies about physicians and hospitals as death houses, and social distancing being a violation of cultural norms and values. The major impacts are observed on education, economy, psychological wellbeing, and socio-cultural practices. This study provides a roadmap for policymakers and future scholars to understand socio-cultural, educational, economic, and psychological problems that emerged due to COVID-19 Pandemic.
\end{abstract}

Keywords: COVID-19 Pandemic, Socio-Cultural, Economic, Educational Impacts, Qualitative Research

\section{Introduction}

The opening of educational institutions in Pakistan was a challenge during the COVID-19 pandemic because it brought many myths and superstitions with itself, have negative impacts on society. The government took pauses at different periods to overcome the spread of the virus due to the reason that every corner of the world is hit by the pandemic. Although, the first case was reported in China on November $17^{\text {th }}, 2019$, in a short period of 4 months. It was declared to be a global pandemic on March $11^{\text {th }}, 2020$ by World Health Organization, thus, causing widespread fear, anxieties, and deadlocks. Xiao (2020) reported that COVID-19 not only brought deaths to many people but an era of fear and psychological distress all over the world. Thus, COVID-19 has badly impacted the routine life of individuals and the patterns of rituals and rites, and the patterns of behaviors within certain events (Seraphin, 2020).

In Pakistan, the first case was reported on February $26^{\text {th }}, 2020$ who was a student at the University of Karachi. The situation became worse by March $23^{\text {rd }}, 2020$ and the government imposed a nationwide lockdown. The completed lockdown was changed into 'smart lockdown' on May $9^{\text {th }}$, 2020 however the educational institutions and big markets remained closed (Kaleem, 2020), but smart lockdown is considered a weak strategy to curb the corona spread. The persistent increase in the number of COVID-19 positive cases needed an elevated level of activities, plans, actions, and management. Already on February $12^{\text {th }}, 2020$, the Ministry of National Health Services, Regulation, and Coordination introduced a National Action Plan for Preparedness \& Response to COVID-19 in Pakistan. The objectives were to control the spread of infection and reinforce the national and network

* Department of Social Work \& Sociology, Kohat University of Science \& Technology, Kohat Email: janalam@kust.edu.pk

** Department of Social Work \& Sociology, Kohat University of Science \& Technology, Kohat Email: akhtar_psw@yahoo.com

*** Department of Social Work \& Sociology, Kohat University of Science \& Technology, Kohat Email: noman.khattak17@gmail.com 
crisis management to guarantee an ideal, proficient, and compelling reaction to expected impacts because of COVID-19. Controlling the pandemic was a challenge because every segment of the population interpreted it differently. For example, some people took it very seriously and became health conscious whereas some people took it too lightly because they rejected wearing masks and use sanitizers and many others called it propaganda.

Until this point in time, various measures have been taken by the Government of Pakistan against the COVID-19 pandemic. To better understand the local perspective about COVID-19, this study applied an interpretive approach. Appreciating that social reality is a complex phenomenon, this study explored the socio-historic context and subjective interpretations of the participants about the CVOID-19 pandemic as per the method recommended by (Denzin, 1997; Denzin \& Lincoln, 2000). Considering the existing facts and figures, the study was undertaken under the following research questions.

Research Question 1. What are the socio-cultural and psychological effects of COVID-19 in northwest Pakistan?

Research Question 2. How COVID-19 pandemic affected education, the economy, and the developmental sector?

The study proceeded with the following objectives.

Objective 1. To explore the socio-cultural and psychological effects of COVID-19 in northwest Pakistan.

Objective 2. To discover the effects of the COVID-19 pandemic on education, economy, and developmental sector.

\section{Literature Review}

The contemporary world is facing a global medical emergency in the shape of COVID-19. The Coronavirus has hit the whole globe creating restlessness and fear as the transmissibility is increasing day by day (Zhao et al., 2020; Quadri, 2020). The rapid spread of the virus and morbidity rates leads to emergency health measures, physical distancing, and lockdowns which resulted in unprecedented impacts on employment, social interactions, and, the world economy. Social distancing, washing hands with soap, sanitizers, and face masks were considered mandatory for controlling the spreading of the virus (Pandey et al., 2020). With the passage of time and the constant spread of the illness, suspicious ideas, unrealities and accuse games, thrilling media announcing of COVID-19, disappointment and fatigue, usage of community lockdown, absence of individual space at home, and family financial issues cause psychological distress. There have been various reports about the psychological effects of the pandemic on the overall population, the staff of medical services, and students (Zhao et al., 2020).

Modern science reveals that corona is a communicable disease caused by a coronavirus in which the patients suffer from various symptoms including cough, throat infection, and fever. It also had some typical symptoms i.e. runny nose, sore throat, diarrhea, and aches pain which may continue till 5-6 days, maybe fatal (Pandey et al., 2020). The World Health Organization proclaimed the COVID-19 outbreak as the $6^{\text {th }}$ public health emergency on January $30^{\text {th }}, 2020$ (Bilgin et al., 2020). This was not the first episode of the corona, the past outbreaks including Severe Acute Respiratory Syndrome (SARS) infection and Middle Respiratory Syndrome infection (Zhou et al., 2020).

In Pakistan 361,082 were confirmed cases up to November 17, 2020, in which active cases are 29,055, deaths were 7,193 while 324, 834 patients were recovered from the corona. Furthermore, in Azad Jammu and Kashmir, the total confirmed cases were 5,538, including 1,336 active cases, deaths were 126 while 4,076 patients were recovered, in Baluchistan, the total conf irmed cases were 16,449 , active cases are 391, deaths were 156 while 15,902 patients were recovered. Similarly, in Gilgit Baltistan the total confirmed cases were 4,461, active cases are 161, deaths were 93 while 4,207 patients were recovered. Alongside, in Islamabad the total confirmed cases were 24,444, in which active cases were 3,686, 260 deaths occurred while 20,498 patients recovered from the disease. Meanwhile, in Khyber Pakhtunkhwa the total confirmed cases were 42,615, active cases were 2,190, deaths were 1315 while 39,110 patients recovered. In Punjab the total confirmed cases were 111,047, active cases are 10,766, deaths were 2492 while 97,789 patients were recovered and in Sindh, the total confirmed cases were 156,528 , active cases were 10,525 , deaths were 2751 while 143,252 patients were recovered (Govt. of Pakistan, 2020). 
Hence, the widespread corona has many effects on societies. For example, Zhang et al. (2020) reported that the pandemic of COVID-19 has serious psycho-social effects on the public, particularly those quarantined and subsequently with restricted face-to-face communication. They suffer from anxieties, fear, fatigue, miseries, and superstitions. Overall, COVID-19 has negative psychosocial impacts as several studies linked loneliness and social is olation to poor mental health outcomes. These impacts may be severe for older adults and adolescents. The existing literature also reveals symptoms of depression and anxiety and self-reported stress as reactions to the pandemic of COVID-19 (Aylie et al., 2020).

Similarly, like other segments of a population, university students also suffered due to this pandemic. UNESCO (2020) reported that more than 1.5 billion students suffered around the globe from the COVID-19 outbreak. To a large number of students, the COVID-19 pandemic is the foremost health crisis they have ever experienced. Around the globe educational institutions were closed and teaching was shifted to an online mode of teaching and learning. Exams were canceled which has affected students both in the short and long term. In the higher education sector, online assessment has replaced the traditional exam system. However; this was a new experience for both the students and teachers and the careers of this year graduates were also severely affected by the outbreak of the pandemic (The Nation, May 13, 2020).

In the ongoing COVID-19 all public health measures have been taken by the governments to control the spread of the virus. However, religious activities need face-to-face interaction due to the identities, beliefs, practices, and community structures, which was a challenge for the government. Furthermore; mourning, deaths, and rituals also require face-to-face interaction, but the concept of social distancing somehow impacted all these activities around the world (Baker et al., 2020). Moreover, Bentzen (2020) stated that the COVID-19 pandemic brings chaos and instability in the world and the use of religion by the believers in unexpected situations and hard times. This study also reported that during March 2020, the most frequent search for prayers on google was the "coronavirus prayers" for protecting and strengthening against the coronavirus. The study also reported that the search for prayers was more in poor, insecure, and developing countries as these countries are the most traditional ones having a poor healthcare system(Bentzen, 2020; Meza, 2020).

Hence, the pandemic raises various significant analytical contemplations for experts, from intra-individual and intuitive, to bigger hierarchical and cross-public consequences. At any rate, religious scholars will need to pay thoughtfulness regarding how strict experts have adjusted their authority to oblige social isolation, changing to a generally far-off workplace. Similarly, as the conditions encompassing the pandemic have caused numerous individuals to reevaluate such fundamental issues as racial disparity, medical services arrangement, what's more, the part of instruction in a flourishing society, the ordered "delay" may permit religious scholars the existence to all the more completely redo the examination of religion in the twenty-first century, and to create inventive ways to deal with seeing how religion keeps on shaping individuals' lives (Baker et al, 2020).

\section{Some General Pakistani Health Myths and Supe rstitions}

Every society has its myths and superstition about health and society and whatever occurs around them. These play an important in their ideas about attaining fortune and avoiding misfortune, these may be false or factual (Zaidi, 2020; Fatima, 2016). Thus, these are an important aspect of the ir daily social activities regarding many aspects of their life including health and illness. Some of the common Pakistani myths and superstitions are,

\section{Nazr or Nazr-e-Bad is well-known}

$N a z r$ or an evil eye is a general perception about someone whose eyes have the power to damage the health, property, or anything of worth value when he/she sees that. It is easier to be done, as it only requires a single glance, admiration, or jealousy directed against the person against whom Nazr is planted. There are no factual findings of Nazr, some people consider it as a religious superstition whereas many consider it as a cultural myth.

In Pakistani society, many people are highly cautious about protecting the Nazr or evil eye, as they consider it to be destruction for them. These may include avoiding the disclosure of their status, plans, achievements, and property such as cars and buildings (Zaidi, 2020). To avoid Nazr, people wear amulets and hang old shoes in front of their cars and buildings, whereas some people also associate illness or disease with an evil eye (Field Survey, 2019). 


\section{Nails or hair cutting at night}

Similarly, Zaidi (2020) also reported that another common myth is the cutting nails or hairs in the night, will probably invite the evil spirits. The evil spirits will collect these and will use them in casting black magic against the person or the family members. Some people also believe that stepping on a person's hair will cause a serious headache.

\section{A pers on who is sneezing is missed by someone}

According to Songu and Cingi (2009), sneezing, or sternutation, is a semi-automatic and abrupt expulsion of air from the lungs through nostrils and mouth, allowing the discharge of mucus. It is mainly caused by certain allergies, a viral infection, exposure to bright light, or the entrance of any foreign particles to the respiratory tract or lungs. However, sneezing has a different interpretation among some people in Pakistan. It is believed that a person who sneezes may be missed by someone (Zaidi, 2020), thus he or she must immediately call his/her family and discover their well-being.

\section{The Jinnat/Spirits also well-known}

The Jinnat or Spirits/demons are derived from Arabic and Islamic literature. They have the supernatural quality to occupy the shape of humans and certain animals. They are made of fire and air and cannot be seen by human beings (El-Zein, 2009; Zaidi, 2020). People in Pakistan believe that Jinnat mainly roams in the night and is mostly found in graveyards, old buildings, and trees. They may tease a person if he uses perfume at the night, take bath after sunset, or sit under a tree at the night (Zaidi, 2020; Fatima, 2016). Many people believe that a person who suffers from a psychological problem (i.e. Schizophrenia etc) is caught by Jinnat/spirits.

\section{Twitching of left or right eye}

The twitching of the left eye is a sign of something bad is going to happen whereas, if the right eye twitches, is an indication of good luck (Zaidi, 2020). However, there is no rational fact about such superstitious beliefs. Modern science reveals that eye twitching or Blepharospasm is an irregular shrinkage or twitch of the eyelids. Its exact causes are unknown; however, some scholars believe that it may be because of stress, fatigue, and or the use of excessive caffeine (Simpson et al., 2016).

\section{The $s$ weeping floor in the night}

It is a myth in some parts of rural Pakistan that sweeping home or room in the evening or at night will brush away the good luck. It will also decrease the earning or employment opportunities, or it may attract an unwanted guest or an evil stranger (Zaidi, 2020), and the person or his/her family members may fall ill.

\section{Corona, beliefs, rituals, and the role of cle rgy}

The beliefs and prayers are important dimensions of every society, having a diversified role in different societies. Beliefs have significant impacts on various aspects of society including health and the provision of both preventive and curative services. According to National Service for Complementary Medicines (NCCAM), prayers have the spiritual power of appeal and satisfaction especially in health issues, including prayers by a sick person him/herself or by someone else such as family members (Krucoff et al., 2006). Moreover, prayers are the divine intervention to accomplish well-being and safeguard oneself from any injury or hazards.

The exponents of spiritual healing advocate that prayers have the power to overcome the serious implication of any disease, it also speeds the recovery process and increases the efficacy of medicines. The beliefs and confidence over rituals are believed to improve coping with the disease and give comfort during the ailment. Hence, sick people are advised by the clergy to take part in religious practices as these can ail different diseases like cancer, mental disorders, heart diseases, and any other health problem, however, challenging the scientific shreds of evidence (Krucoff et al., 2006). Therefore, many medical or psychiatric patients are performing re ligious and spiritual practices to overcome their illness and other psychological sufferings (Churchill, 2007; Ernst, 1995).

Moreover, studies on religious behaviors revealed a direct correlation between fear and beliefs. Two casual links were exposed by these studies; the first one is that fear motivates the faith in religion and then the religious faith alleviates fear (Meza, 2020). Jackson et al. (2017) reported that religious people could enjoy a lesser level of depression and anxiety because of their faith, belief system, norms, rites, and community ties. However, on the other side of the coin, some studies also showed that belief can increase the fear of death (Ellis et al., 2013). Religion also provides the possibility to think beyond the contemporary situation and accept the reality of senses, worldview, and multiple words (Meza, 2020). 
According to Le et al. (2007) and Trevino (2010), healing through spirituality can have different forms, these are mainly prayers performed in silence or loud voice while sitting in isolation or any religious congregation. Some people alongside prayers in the Mosque, Church, or temple, regularly visit a sacred place like shrines and pilgrimage for healing. They take sacred water, salt, and amulets for healing, us ing these on a routine basis like medicines. Pakistan being the Islamic Republic of Likewise, Pakistan is an Islamic ideological state, where many laws, policies, beliefs, and rituals are applied and perform according to the Islamic law i.e. Sharia. According to Afzal (2020), the government of Pakistan is under the pressure of a group of Islamic Parties (such as Jamiat Ulema e Islam and Jumat e Islami). Hence, the same is observed in the application of government policies against the control of the widespread corona epidemic. Thus, there are more chances of corona spread in Pakistan due to such a rejection, weak healthcare system, unhygienic practices, unavailability of health services, and the ignorance of the masses. However, the scientific evidence supports the signif icance of social distancing as a preventive measure against COVID-19 (Koo et al., 2020), which requires strong public support for successful implementation. The very poor practice of social distancing has been observed in Pakistan because of the lack of support from the clergy and the local masses. Both classes believe that the closing of mosques and the ban on collective prayers is a sin (Sajid, 2020).

Likewise, in April 2020, a most well-known Pakistan Islamic scholar namely Maulana Tariq Jameel revealed in his address on television that COVID-19 is an indication of God's anger due to the sins committed by women as they wear indecent dressing. Thus, most of the people started believing that coronavirus can not harm as Muslims are more immunized through ablution for five times prayers as they wash their face and hands daily. Muslims because it is God's anger against the nonMuslim/infide ls" due to their immoral deeds (Aamir, 2020; Khattak, 2020).

Similarly, a major segment of society, who are most affected by strict religious advocacies, accept that COVID-19 is a plan brought forth by some infidel/non-Muslims to buffer Muslims from performing prayer at mosques and follow ing their religion. Similar propaganda also exists about polio vaccinations that are used against Muslims to make them infertile to reduce their population (Khattak, 2020). Thus, it is evident that the preventive measures against any novel disease are mispredicted among the population by referring it to interference in the religious doctrine by linking it the conspiracies against Muslims.

Another whimsical idea is that the COVID-19 is essentially a plan to make China a superpower, but China being the friend of Pakistan will not harm it. Many people also blame Bill Gates, the Owner of Microsoft Company, that he has paid a huge sum of money to create coronavirus and spreading the infection so he can earn more money by selling its antibody (Aamir, 2020). Thus, there is no coronavirus, it is only a Jewish plan to install a chip in the vaccine to observe the moment of Muslims (Gillani, 2020). Some of the people also expressed that the government is intended to make money from international donors by reporting more cases of corona (Khattak, 2020; Gillani, 2020).

\section{Methodology}

The study was qualitative as this methodology becoming more widespread and significant in social sciences particularly in the field of sociology, community development, and education (Marshall \& Rossman, 1999). Purposive sampling technique was used for sample selection due to the nature of the study, only those participants were selected who could better explain and respond to the questions asked during the interview sessions as revealed by (Oppong, 2013). The sample size for this study consisted of 24 participants recommended by Creswell (2014) that the optimum sample size for a qualitative study maybe 20-30. Thus, 6 participants each from FATA University, Kohat University of Science and Technology, Preston University Kohat, and The University of Peshawar were selected. The participants were interviewed face-to-face, alongside online interviews were also conducted with those participants who felt uneasy with face-to-face communication. An open-ended interview design was used to explore the perspective of the students and their experiences about the COVID-19 pandemic. The COVID-19 SOPs were strictly followed by the researchers in the field during data collection. The primary data were analyzed by applying the thematic analysis method; bas ic themes, organizing themes, and global themes given by Stirling (2001). The confidentiality of the participants was ensured by assigning pseudo names to them during data analysis and discussion. 


\section{Discussion}

This section analyses the participants' discourse about the myths, superstitions, and the perceived impacts during the COVID-19 lockdown. The views of the participants were analyzed through an interpretive approach to have a more in-depth understanding of the problem. In this context a participant Haroon responded that;

"I face so many problems including depression and tension in the COVID-19 pandemic. Every time I thought that I am having corona due to which I remained tense and sick. I was unable to move around as the government and our parents did not allow us to go outside and enjoy which on the other hand badly affected my mental status."

\section{COVID-19 Pande mic affe cts over routine activities}

The participant reflected the scenario of the corona pandemic in such a way that it made the people so nervous and suspicious that people start exploring the symptoms of corona in themselves which alternatively leads them to tension, depression, and anxiety. Outside activities were also either banned or minimized and most people were staying at home which also caused frustration and depression among individuals. Moreover, some of the participants considered the coronavirus as a disaster for our religious and social activities.

A Participant namely Majeed Responded that,

"Well honestly speaking corona had bad impacts on our religious activities and social life. People stop attending the wedding ceremonies, funerals and stop meeting with others, people always feared that they may be infected".

Another participant Shahid responded that;

"We must not be afraid of this disease. Those who are afraid have weak Islamic faith (i.e. Eman). People should not take this disease very seriously, we are Muslim and offer five times prayers daily, ablution is the real weapon with which Muslims can protect themselves against coronavirus.

Thus, it is a fact that with this pandemic religious and social activities suffered to a great level. The weddings and funerals are not performed according to the traditional ways, it was either not celebrated or minimized. Though the government has also developed certain SOP's in some cases people do not seriously take the matter.

A Participant Sajid responded that:

"I heard from our Imam e Masjid/Cleric that this disease is a curse, and only those will suffer from it who are doing evil deeds. Those who regularly pray to God, will not suffer from it. Moreover, it is a conspiracy against Muslims to weak their faith and stops them from performing Haj i.e. Pilgrimage and prayers in the Mosques."

A participant namely Waseem expressed that;

"Many people do not follow the precautions against corona, as they think that all those who suffer from it are caught by an evil eye, and thus those who regularly whisper the Quranic verses or wear amulets will be protected from it."

A participant namely Zubair responded that;

"I believe that Muslims do not suffer from Corona, as it spreads due to eating bats and mice. Muslims do not eat these things, thus are protected from them. Moreover, it is just propaganda spread through social media. If we close our Mosques and Madrassas, Allah will be unhappy and will curse us."

\section{Corona and the Health conspiracies}

This study further explored that some people who suffered from flu, fever, or even corona did not visit the physician, due to the fear that he/she will be admitted to the hospital, putting $\mathrm{him} / \mathrm{her}$ name in corona list and will kill him/her. There is a common Pashto proverb " $A$ prolonged fever is an indicator of death". Thus, many people considered the hospital as "Death House", and they even did not visit the hospital even in case of any other disease, they suffered from.

Similarly, a participant namely Usman added that,

"People in our Mohalla do not visit a doctor in case they suffer from any disease. They go to religious clerics and spiritual healers, because if they visit a doctor, he will send them for 14 days in quarantine, someone may die there." 
Another participant Mustafa added,

"You know, people did not trust the hospital authorities during the pandemic period because they believe that they will be put on the corona patient list. There will be no one to take care of them in quarantine, thus they will die even they did not suffer from the corona."

Lockdown, social distancing, and unemployment

The wave of coronavirus developed an unseen fear among the people due to which the decisionmaking power of the people was also disturbed. Initially, people were not following SOPs due to religious beliefs and misconceptions in the community. However, over time, people start realizing the importance of following the SOPs and adjusted their life accordingly to the pandemic. However, many people became unemployed due to lockdown, hence, numerous people were unable to support their families, thus their psychological problems leading to depression and anxiety increased. Similarly, as revealed by Amjad,

"Initially we started thinking too much about the corona without following the SOPS which makes us more tensed, worried, and depressed. Gradually people start living with the pandemic and adjusted their life accordingly as there was not much moment within the communities and people usually remained in social isolation. They could not perform their economic activities to earn their livelihood, thus, suffered from anxiety and depression. Many of them became unemployed to lockdown."

Hence, the coronavirus not only brings public health problems but also unemployed at a large level not only around the world but also in Pakistan, and this situation caused psychological problems among the people.

A participant named Ali linked coronavirus with the fear of infection according to him;

"Due to the fear of corona I stopped going to the markets, university, bank, etc as I was afraid, I will be infected; though I followed all the SOPs related to corona. Coronavirus has created the fear of death as some people lost their lives due to the virus. We reduced our moment and start following the SOPs strictly which on the other hand restricted our social life and we remained in self-isolation leading us to fear, depression and anxiety".

In continuation of this, another participant Zahid also expressed that

"Unemployment in our area increased due to pandemic. It affected both the social and economic aspects of life. It was a disaster all around the world making people unemployed and mentally sick which badly affected their social life".

\section{Psychological effects}

Social life was disturbed as it was chaos all around and the people were living in a period of uncertainty, fear, unemployment, or underemployment and worries, as some participants linked depression with fewer earnings in the period of coronavirus. A participant Hameed expressed that,

"Lockdown in our areas causes serious effects leading to anxieties and depression. The earnings of people were affected in the period of the pandemic, so those who are earning a lesser amount of money remained more disturbed, tensed, and depressed. In contrast, some people were careless and do not following the SOPS as they think that being a Muslim everything is written in the fate and everything is already written so their social life was not disturbed by the coronavirus".

Though some people were unemployed or under-employed in the pandemic somehow the Islam provided them with a hope that all things were written in fate and this situation will be overcome soon. There was also a difference in the rural and urban set up as a participant Mohib added that;

"Well frankly speaking we were not taking the virus so seriously through we do hear about its impacts on the world but being from a rural setup we do not take serious note of all these stuff, however; the government tried to have a strict implementation of the SOPs as our playgrounds were closed forcefully by the police".

Hence, the government has implemented strict SOPs for the pandemic, but its implementation was not that strict in rural areas as compared to urban areas due to various socio-cultural and religious factors. Many people also considered it as a violation of Pakhtunwali customs (A Pakhtun code of life), they do not follow social distancing and always shake hands with guests or newcomers to their Hujra i.e. Pakhtuns' Guest House as responded by a Participant Ahmad, 
"I feel sad to observe that people in our area do not follow SOPs such as avoiding handshake and social distancing. People regularly attend marriage ceremonies and greet the guest by handshaking or embracing each other. The local masses reject SOPs, considering it as a violation of their custom and traditions".

It is also observed that the Pandemic has increased social bonds among the family members, tribes, and clans. It brought those closer to their families or tribes who could not allocate enough time to their families or taking part in customary activities. A participant Shahzad added,

"Well due to the coronavirus pandemic, we spent more time with the family which helps in developing a more powerful sense of belongingness among us. It also helped to understand the various dynamics within the family system due to discussion on various family-related issues".

Similarly, Hafeez also opined that,

"It was an opportunity for us to give enough time to our family members and friends.

I have spent most of my life outside the village in the education and job sector. However, this pandemic provided me with the opportunity to spend more time in my village and with the people of my community which helps in developing a strong social bond with them".

\section{Corona as a barrier to Education}

Corona has many negative outcomes over education and economy, family life, and politics. Due to lockdown, students in Pakistan could not attend schools, colleges, and universities for many months. During the period of complete lockdown, an online education system was introduced, however, the students faced many problems, given below,

A participant namely Kabir shared his experience of education during the pandemic,

"Academically I faced enormous problems including lack of concentration on the study, no internet access for online education. I was unable to understand anything in an online class, thus I could not get good grades in the examination".

Another Participant Sameen also added that;

"After the pandemic and health emergency declaration by the government, the mode of education was changed to online education, which was not welcomed by many of the students. Most of the students do not have the desired equipment required for online education including laptops, smartphones, and internet access which affected their academic performance".

There are certain areas, especially far-flung areas such as former-FATA regions, where there is no internet access or facilities. Those students, who belong to such areas suffered from many problems especially the absence of internet facility in their homes, as revealed by a participant namely Kamal,

"At the beginning of the pandemic the government realized the severity of the problem, so they closed all schools, colleges, universities, offices, and markets. The online education system was introduced in the country but unfortunately, there were internet access issues particularly for the students living in the remote areas of erstwhile FATA".

The importance of face-to-face interaction for the learning process cannot be underestimated, the mode of teaching and learning was changed. Thus, the education and socialization process of children was also negatively affected. In addition to this, a participant Rizwan also stated that,

"The schools were closed from March 2020 till date, which has negatively affected the academic performance of the children but also has negative consequences on their socialization process. Internet was the main issue; we could not interact with our teachers in case we had any question about the course/lesson".

The impacts of online education were not encouraging which was also reported in the various examination conducted by the universities. A participant namely Asim recalled his experience with online education and examination by saying that;

"Well, it was a disaster as we not only faced internet and electricity issues during the online classes but also faced problems in examinations and assignment submission. Once I was attempting a paper and no electricity was available which have badly affected my performance in that particular paper". 


\section{Pandemic and the welfare activities}

Life was difficult during the pandemic, many people needed economic support. Hence, charities and cooperation (as a virtue) played an important role in providing livelihood to the needy ones. A participant Sajid expressed that,

"In the period of pandemic people became more religious as they were fearing from the virus and were more inclined to prayers and asking Almighty Allah to forgive their sins. Thus, a sense of moral and ethical development was observed. Many people gave charities to get the blessing because they believe that charity protects from troubles."

As mentioned, that this pandemic increased the concept of charities i.e. Sadaqat in the community. Free food and necessities of routine life were provided to people who are in need by the well of people of that area to receive the blessings of Almighty Allah. A participant Shahzeb stated, "Welfare in the name of religion helps to minimize the economic problems faced by the masses. In the pandemic period, the level of charities in the form of cash and food items was increased in the name of Sadaqat ${ }^{1}$, which is an important aspect of an Islamic society."

\section{Conclusion}

This study was designed to explore the socio-cultural, economic, educational, and psychological impacts of the COVID-19 Pandemic. To conclude the experiences of university students, the researchers have been able to put forward new knowledge in terms of effects on education, economy, emotional disturbance, and increased health conspiracies and superstitions. These included the beliefs and superstitions about the prevention and existence of corona, health conspiracies such as hospitals as death houses, and violation of Pakhtunwali and barriers of education and economy, and their consequences on students and the local population.

This study also offers an understanding of those factors that are important in providing preventive and curative services against corona, the policymaking by government, or any nongovernment organizations, especially the application of SOPs in academia. Finally, this research study also expresses the methods and use of a qualitative approach to new knowledge by exploring the deeply rooted factors of a phenomenon. Hence, this study also provides a framework for future scholars of medical sociology, psychology, philosophy, education, and economics to study the COVID-19 pandemic from different dimensions.

\section{References}

Aamir, A. (2020). Conspiracy theories help coronavirus take root in Pakistan Retrieved from; https://asia.nikkei.com/Spotlight/Coronavirus/Conspiracy-theories-help-coronavirus-takeroot-in-Pakistan

Afzal, M. (2020). Pakistan's dangerous capitulation to religious rights on the coronavirus. Retrieved from https://www.brookings.edu/blog/order-from-chaos/2020/05/04/pakistans-dangerouscapitulation-to-the-religious-right-on-the-coronavirus/

Aylie, S. N., Mekonen, A. M., \& Mekuria, M. R. (2020). The Psychological Impacts of COVID-19 Pandemic Among University Students in Bench-Sheko Zone, South-west Ethiopia: A Community-based Cross-sectional Study. Psychology Research and Behaviour Management, $13,813-821$

Baker, O. J., Marti, G., Braunstein, R., Whitehead, L. A., \& Yukich, G. (2020). Religion in the Age of Social Distancing: How COVID-19 Presents New Directions for Research. Sociology of Religion: A Quarterly Review, 81(4), 357-370.

Bentzen, J., S. (2020). In a crisis, we pray religiosity and the Covid-19 pandemic. In: Wyplosz Ch (ed) Covid economics. Vetted and real-time papers. pp 52-108

Bilgin, S., Kurtkulagi, O., Kahveci, G. B., Duman, T. T., \& Tel, B. M. A. (2020). Millennium pandemic: a review of coronavirus disease (COVID-19). Experimental Biomedical Research, 3(2), 117-125.

Creswell, W., J. (2014). Research design; qualitative, quantitative, and mixed methods approach. California: Sage publication.

Churchill, L, R. (2007). The dangers of looking at health beliefs of religion. Lancet, 369, 1509-1510

\footnotetext{
${ }^{1}$ Sadaqat or Sadaqah in the modern context has come to signify "voluntary charity". According to the Holy Quran, the word means voluntary offering, whose amount is at the will of the "benefactor".
} 
Denzin, N. (1997). Interpretive ethnography: Ethnographic practices for the 21 st century. Thousand Oaks, CA: Sage

Denzin, N, K., \& Lincoln, Y. (2000). The seventh moment: Out of the past. In N.K. Denzin and Y. Lincoln (eds), Handbook of qualitative research, 2nd edn (pp. 1047-65).

El-Zein, A. (2009). Islam, Arabs, and Intelligent World of the Jinn. Syracuse University Press. p-38 ISBN 9780815650706

Ernst, E. (1995). Complementary medicine: common misperceptions. J Royal Society Med, 88(5), 244-247.

Fatima, S. (2016). Seven popular superstitions among Pakistanis. Retrieved from; https://nation.com. pk/25-Jan-2016/7-popular-superstitions-among-pakistanis

Ellis, L., \& Wahab, E., A. (2013) Religiosity and fear of death: a theory-oriented review of the empirical literature. Review of Religious Research, 55(1),149-189.

Gillani, W. (2020). Dangerous theories. Retrieved from; https $/ / / \mathrm{www} \cdot$ thenews.com.pk/ tns/detail/674847-dangerous-theories

Government of Pakistan. (2020). COVID-19 Dashboard: COVID-19 Cases in Pakistan. Retrieved November 17, 2020, from https://covid.gov.pk/stats/pakistan

Jackson, J., Jong, J., Bluemke, M., Poulter, P., Morgenroth, L., \& Halberstadt, J. (2017). Testing the causal relationship between religious belief and death anxiety. Religion, Brain \& Behavior, 8(1), 57-68. https://doi. org/10.1080/2153599X.2016.1238842

Kaleem, M., F. (2020). Educational institutions to stay closed till July 15; board exams canceled. https://dailytimes.com.pk/609118/educational-institutions-to-stay-closed-till-july-15 board exams-

Khattak, D. (2020). Pakistan's Confused COVID-19-19 Response. Retrieved from https://thediplomat.com/2020/06/pakistans-confused-COVID-19-19-response/

Koo, J., R, Cook, A, R., Park, M., Sun, Y., Sun, H., \& Lim, J, T. (2020). Interventions to mitigate the early spread of SARS-CoV-2 in Singapore: a modeling study. Lancet Infect Dis, 3099(20), 30162-6.

Krucoff, M., W., Suzanne W. Crater, S., W \& Lee, L., K. (2006). From efficacy to safety concerns: A step forward or a step back for clinical research and intercessory prayer? The Study of Therapeutic Effects of Intercessory Prayer, 151(4):762-4.

Le, T., N., Tov, W., \& Taylor, J. (2007). Religiousness and depressive symptoms in five ethnic adolescent groups. International Journal for the Psychology of Religion,17(3), 209- 232.

Marshall, C., \& Rossman, G. B. (1999). Designing qualitative research (3rd ed.). Sage Publications, Inc.

Meza, D. (2020). In a Pandemic Are We More Religious? Traditional Practices of Catholics and the COVID-19 in Southwestern Colombia. International Journal of Latin American Religions. DOI: https $/ /$ doi.org/10.1007/s41603-020-00108-0

Oppong, H., S. (2103). The problem of sampling in qualitative research. Asian Journal of Management Sciences and Education, 2(2), 202-210.

Pandey, K. A., Gupta, R., \& Singh, A. (2020). Traditional Remedies and COVID-19: A Qualitative Exploration of Indigenous Resources. Plant Archives, 20(2), 2066-2069

Quadri, A. S. (2020). COVID-19 and religious congregations: Implications for the spread of novel pathogens. International Journal of Infectious Diseases, 96, 219-221.

Sajid I. (2020). COVID-19: Pakistan to allow mosque prayers in Ramadan. Retrieved from https://www.aa.com.tr/en/asia-pacific/covid-19-pakistan-to-allow-mosques-prayers-inramadan/1810144

Seraphin, H. (2020). COVID-19: an opportunity to review existing grounded theories in event studies. Journal of Convention \& Event Tourism. DOI: https://doi.org/10.1080/15470148. 2020.1776657

Simpson, D. M., Hallett, M., Ashman, E. J., Comella, C. L., Green, M. W., Gronseth, G. S., Armstrong, M. J., Gloss, D., Potrebic, S., Jankovic, J., Karp, B. P., Naumann, M., So, Y. T., \& Yablon, S. A. (2016). Practice guide line update summary: Botulinum neurotoxin for the treatment of blepharospasm, cervical dystonia, adult spasticity, and headache. Neurology. 86(19): 1818-26.

Songu, M., \& Cingi, M. (2009). Sneeze reflex: facts and fictions. Ther Adv Respir Dis, 3(3), 131-141. 
Stirling, A., J. (2001). Thematic networks: an analysis tool for qualitative research. Qualitative research, 1(3), 385-405

The Nation. (May 13, 2020). COVID-19's impact on education. Retrieved November 28, 2020, from https://nation.com.pk/13-May-2020/covid-19-s-impact-on-education

Trevino, K, M., Pargament, K, I., \& Cotton, S. (2010). Religious coping and physiological, psychological, social, and spiritual outcomes in patients with HIV/AIDS: cross-sectional and longitudinal findings. AIDS and Behavior, 14(2), 379-389.

UNESCO. (2020). Global Education Coalition. Retrieved December 1, 2020, from https $/ /$ en.unesco. org/covid19/educationresponse/globalcoalition

Xiao, C. (2020). A novel approach of consultation on 2019 novel coronavirus (COVID-19) related psychological and mental problems: structured letter therapy. Psychiatry Investigation, 17(2), 175 .

Zhang, Q., Wang, Y., Qi, C., Shen, L. \& Jian, L. (2020). Response to Comments on 'Zhang et al: Clinical trial analysis of $2019-\mathrm{nCoV}$ therapy registered in China. Journal of Medical Virology. DOI: https://doi.org/10.1002/jmv.25803

Zhao S, Lin Q, Ran J, Musa SS, Yang G, Wang W, et al. Preliminary estimation of the basic reproduction number of novel coronavirus $(2019-\mathrm{nCoV})$ in China, from 2019 to 2020: Retrieved from http://dx.doi.org/10.1016/j.ijid.2020.01.050.

Zhou, P., Yang, X. L., Wang, X. G., Hu, B., Zhang, L., Zhang, W., \& Chen, H. D. (2020). A pneumonia outbreak associated with a new coronavirus of probable bat origin. Nature, 579(7798), 270-273.

Zaidi, H. 2020. Ten Most Pakistani superstitions. Retrieved from https://www.desiblitz.com/ content/10-most-popular-Pakistani-superstitions 